\title{
The Making of "Illegality": Strategies of Illegalizing Social Outsiders
}

Christine Bischoff

Figure 1

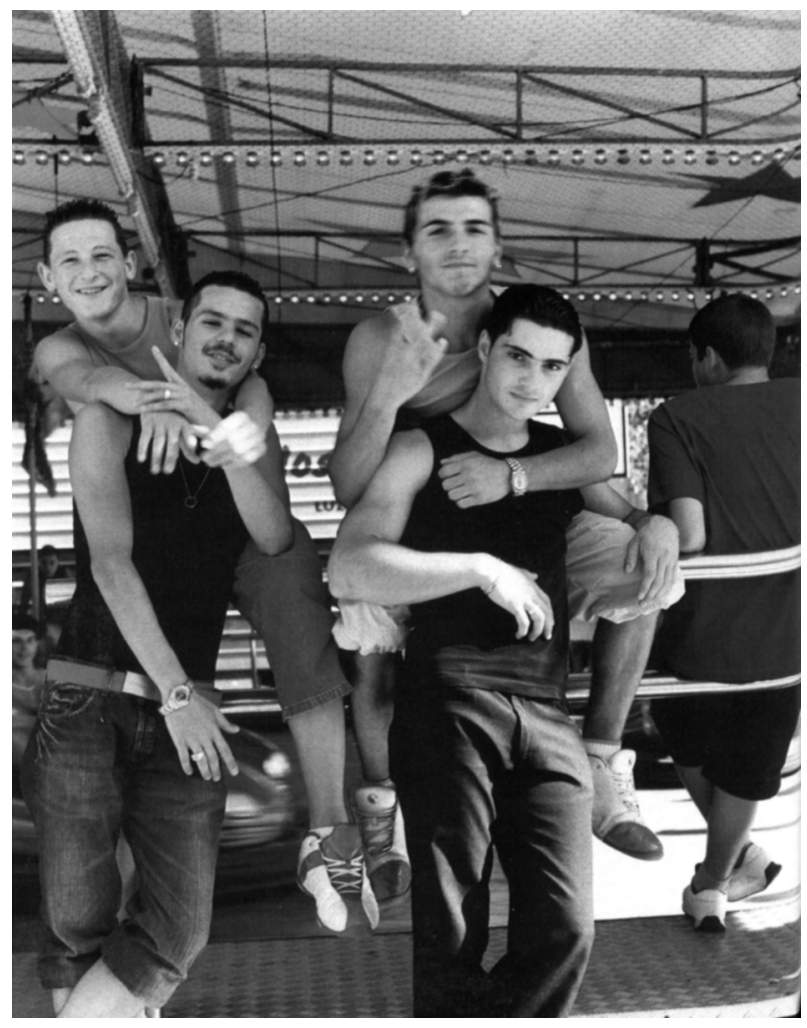




\section{INTRODUCTION}

Iler, Mentor, Albert and Lon. They are posing for the photographer at a Swiss fairground, affecting a "cool" attitude and presenting themselves as a close-knit community-in the typical way young men like to do who are not quite adults or have not been adults for a long time (Figure 1$)^{1}$. These young men are no "illegals" - at least not according to their legal status. They do not only have the permanent right of residence in Switzerland but have spent most of their lives in Switzerland and were even born here. Neither do they conform to our collective image of illegalized migrants which is primarily characterized by exhausted boat people from Africa or by people who, due to their unclear right of residence, live a shadow existence as employed slaves, particularly in the catering or building industries. No, these four men we see in the picture and who were the subject of an extensive photo report in the magazine of the Swiss newspaper Tages-Anzeiger, published in the summer of 2004, do not lead such a life. Nevertheless: On account of their behaviour, their habits, their language, their existence is, in the perception of many Swiss citizens, closely associated with illegality.

Every society has its outsiders - and due to their social and family origins, Iler, Mentor, Albert, and Lon belong to that group in Switzerland which in the eyes of many is prototypical for being not really accepted: the Kosovo Albanians. The media mostly present them as good-for-nothings, neither fluent in Albanian nor German, growing up in between all cultures and being at home in none. Accordingly, the photo report from which the pictures shown here are taken carries the headline: "We, the Cursed". This form of ironic, and at the same time resigned self-description shows that the image conferred from the outside can be integrated as part of one's own identity and, when required, summoned in a kind of self-fulfilling prophecy: Give to a group a bad image and it will correspond to it.

The first significant migration movement from Kosovo to Switzerland occurred in the 1960s and 1970s. These people were classical migrant workers, who intended to work in Switzerland, save money and return home after a short time. The "cursed" are the children of those migrants who came to Switzerland already with the second major migration wave at the end of the 1980s: At that time, repression by the Serbian government became increasingly brutal, and when at the beginning of the 1990 o political violence escalated in Yugoslavia, returning home had become impossible, and in Switzerland a process called "family reunification" got under way. $^{2}$ And those children who today are called "cursed" were confronted with the fact that their admired fathers, who had always been bringing money and presents home, actually had badly paid jobs in Switzerland,

1 | Leuthold 2004, p. 22-33.

2 | For further information about the history of migration of these specific ethnic group in Switzerland see for example: Kämpf 2008.

Bereitgestellt von |Universitaetsbibliothek Basel 
were hardly understood by the authorities, and had a bad reputation with the locals. At school, the children were expected to adjust to Swiss society as swiftly as possible. At home, on the other hand, the parents feared they might be alienated from their own culture. There was pressure from all sides, and in order to survive, these Kosovians quickly had to produce an identity of their own which made it possible for them to react to the most diverse situations.

However, public presentation and perception only rarely interpret this generating of flexible identities as an achievement of these "secondos". On the contrary: they are guilty. Guilty because by the way they are presented-above all visually_in the public media, "boys" such as Iler, Mentor, Albert and Lon succeed in making Swiss citizens livid with rage, triggering political crises and becoming the topic of campaigns which are discussed all over Switzerland. In the year 2004, this media discourse, which turned young men of the second and third generations of immigrants from the regions of former Yugoslavia into the prototype of delinquents, reached its peak. What had happened?

\section{The Speed Maniacs from the Balkans and the Rejected Naturalization Bills OF 2004}

In September, 2004, Switzerland voted on the so called "naturalization bills". Swiss voters were called on to decide whether naturalization should be made easier for the second and third generations of immigrants living in Switzerland by reducing bureaucratic and other obstacles, and whether the Swiss passport should therefore be made more accessible to people of foreign origin born in this country. Apart from making them Swiss nationals, conferring "Swiss citizenship" ${ }^{3}$ would also enable these people to be granted civic rights and obligations as well as political participation. The bills were finally rejected by the popular vote. The remarkable thing is that not only many Swiss citizens but also other migrant groups in Switzerland put the blame for the failure of the bills first and foremost on nationals from the "Balkan region", the so-called "Yugos",- that is, people such as Iler, Mentor, Albert and Lon. This was due to the fact that in the summer of 2004 there was not only a controversial debate in the media over the political vote on the possibility of facilitating naturalization, but the media also created and staged a new "enemy image" and used it as a backdrop against which fundamental integration problems of young migrants in Switzerland were discussed: "The speed maniacs from the Balkans" were born as the mass media's children. ${ }^{4}$

3 | Information about history and specific definitions of "Swiss citizenship" in: Argast 2007.

4 | Bischoff 2006, p. 10-15. 
Particularly the print media mixed reports on the political vote on the possibility of facilitating naturalization with a number of other reports on so-called speed maniacs: reports about young men organizing illegal races on public roads with their tuned cars and causing serious accidents, some of them with fatal casualties. The readers were led to assume that speed maniacs are young, male, automobile-crazy-and that they come from Southeast Europe. The image of the young, male migrant from Southeast Europe's former war regions, giving free rein to his aggressions behind the wheel of a powerful vehicle, was established among the readers by way of this media fabrication of threat. The reports were accompanied by always the same, constantly repeated pictures of wrecked automobiles.

These pictures are characterized by "visual trivialities": at first sight, they do not seem to be very meaningful. However, these apparent picture trivialities prove to be hints, as they allow for the interpretation of meanings which cannot be recognized by help of the "mere" text of the report. In the context of the media debate on naturalization and speed maniacs, these pictures became markers, a "visual allegory" of "reduced willingness to adjust" , something particularly migrants of the second and third generations with Southeast European origin were accused of. The car was presented as the weapon in the hands of unintegratable migrants from Southeast Europe, who in this way became a threat to the entire Swiss society. By way of the visually prestigious object of the car, their apparent dangerousness was made visible. For this strategy of representation, in the course of which what cannot really be shown is made visible, Stuart Hall uses the term "fetishism": "Fetishism takes us to the realm where imagination intervenes in representation; to the level where what is shown or seen by representation can be understood only in relation to that what cannot be seen or shown. Fetishism includes replacing a dangerous and powerful but forbidden power by an 'object'. [...] It permits keeping up the double focus - watching and not watching at the same time." 6 In numerous letters to the editor Swiss people expressed their fear of being killed by these "speed maniacs from the Balkans". If this was to be, at least the maniacs should not be allowed to do this with Swiss passports in their pockets. ${ }^{7}$ Admittedly, this is quite a simplified depiction. But we should not be surprised that media users drew such conclusions.

For weeks and months, the media, particularly the print media, dealt with the question from where these dangerous drivers originated. The media published a number of pictures, preferably pictures of road accidents, maps and most of all infographics to investigate the origins of speed maniacs. For many, the danger came from the East or the Southeast, as is so often the case with xenophobic discourses about foreigners in the European context. A danger, however, for which no statistic or any other evidence

5 | Schär 2004, p. 12.

6 | Hall 2004, p. 154-157.

7 | Tages-Anzeiger September 21, 2004, p. 27. 
could be presented, since Swiss statistics on road accidents do not record categories such as nationalities or ethnic origins. Nevertheless, the media negotiated a whole catalogue of steps that might lend themselves to dealing effectively with the problem of speed maniacs: suggestions made by all Swiss print media were numerous and "loud". Some called for revoking driver's licences in advance ${ }^{8}$ and for confiscating the cars as the "weapons used in the crime" 9 . In letters to the editor the suggestion was discussed to pillory speed maniacs by publicizing the names of legally sentenced speed maniacs. ${ }^{10}$ Others advocated a "forced therapy" for speed maniacs. ${ }^{11}$ A Swiss ex-member of the National Council made the suggestion to send speed maniacs to a "rehab to clean the floors there, or to a hospital where people with severe brain injuries are nursed". ${ }^{12}$ It was also suggested to require people coming from the "Balkans"13 to take an additional driving test for Swiss traffic. And finally the media drew the conclusion that it was high time to explain to the "Machos from the Balkans" what Swiss laws were about. ${ }^{14}$

\section{AMIR B.-The ICON OF EVIL: Criminalization as a Kind of Illegalization}

But media debates also always need new faces. The debate on speed maniacs was given its face with Amir B. All the media portrayed the then 22 year-old who was living in the greater area of Zurich and had come from Kosovo to Switzerland as a child, as the prototype of the speed maniac. In interviews-such as one from the Sonntagsblick-he was quoted with sentences such as this one: "I'm a psycho, after all. I'd rather kill myself than lose a race" (see Figure 2). ${ }^{15}$

In front of the camera of Swiss TV Channel SF 1 he raced against an unidentified competitor in a built-up area. For him, closed-track street races were not an option: "It's much more fun when it's illegal." And his friend, Ahmed, had no inhibitions about stating that he had been riding at a speed of $120 \mathrm{~km} / \mathrm{h}$ in a $50 \mathrm{~km} / \mathrm{h}$ zone.

8 | Tages-Anzeiger September 9, 2004, p. 17.

9 | Neue Zürcher Zeitung October 1, 2004, p. 51.

10 | Tages-Anzeiger September 9, 2004, p. 11.

11 | Ibid, p. 27.

12 | Tages-Anzeiger September 20, 2004, p. 11.

13 | 20 Minuten October 6, 2004, p. 3.

14 | Tages-Anzeiger September 20, 2004, p. 11.

15 | Sonntagsblick September 19, 2004, p. 3. 
Figure 2

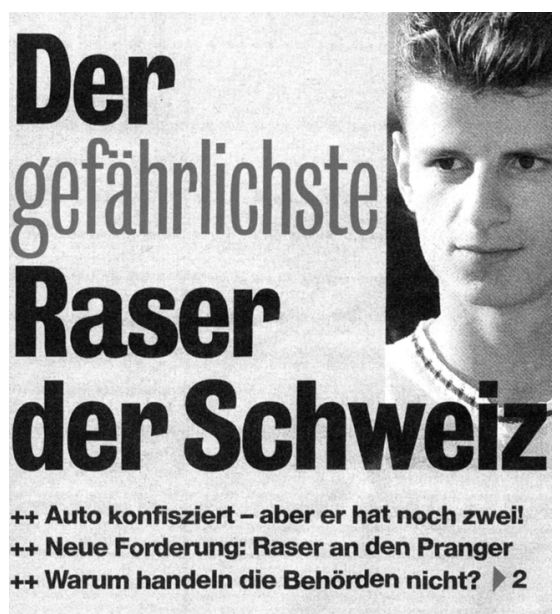

Amir B. became the incarnation of the dangerous speed maniac, who was raised "from the cool tuner to become the nation-wide figure of shame", as it said in one of the original texts of the Neue Zürcher Zeitung. ${ }^{16}$ In Amir, all the elements of an absolutely negative status came together-as is typical for stigmatization and exclusion processes: the migrant status, the lower class status, the criminal status. ${ }^{17}$ The media made this unstable outsider, living at the fringes of society, the focus of societal interest-at least for some time. And he was shown as being representative for everyone with origins in the region of former Yugoslavia. Suddenly, everyone from that region came under suspicion of perhaps being a criminal. And this form of criminalization made it possible to question the legitimacy of their residence status in Switzerland, not necessarily on a juridical, but on a social level. In the public discussion it was now possible to voice the opinion that they were not entitled or no longer entitled to stay in Switzerland.

The topic "speed maniac from the Balkans" was staged by the media as an interaction between a existent social practice in a small group of young people and a discriminating name which was politically instrumentalized and generalized. And it is probably no coincidence that for the migration discourses of the past decades the car is, more than anything else, the leitmotif: often the fathers and grandfathers of those depicted had stood at the assembly lines of the car factories of central and northern Europe, making their crucial contribution to automobile production. In the collective memory, the car is the symbol of the wealth of the rich north. ${ }^{18}$ And now, this symbol of wealth was reduced to scrap metal by the classical migrant workers' grandchildren.

16 | Neue Zürcher Zeitung September 26, 2004, p. 27.

17 | Bude 2004, p. 5; Elias/Scotson 1993, p. 14; Hohmeier 1975, p. 5-24.

18 | Osten 2005, p. 28; Sachs 1990, p. 129-133.

Bereitgestellt von | Universitaetsbibliothek Basel 
For the viewer, these kind of images of male car fanatics evoke scenarios that threaten with violence. Such pictures demonstrate the absurdity of emphasizing the male body. For post-industrial society, the excessively presented male body of the foreign migrant, as we still know it from the 1950s, 1960 s and 1970s, loses economic significance. In modern Western European societies, which like to refer to themselves as knowledge societies, the body, which is a particularly important item especially for men without a good school education, loses its meaning. The strong, healthy body no longer guarantees a place in the labour market of modern migration societies. Indeed, the visual representation the body remains the most important feature of these men (Figure 1). At the same time however, the representation shows them as migrants without a task. These are-to use a term coined by Michel Foucault- "undisciplined bodies", because they cannot be utilized, controlled and disciplined any more by technologies of rationalization and strict economization. ${ }^{19}$ Represented the way they are, the men in fact appear to the viewer as freely moving forces of threat.

\section{The Ethnicization of Everyday Conflicts}

In the debate on speed maniacs in 2004 there was particular emphasis on what was called "belonging to an ethnicity". Previously, speed maniacs, a problem which is almost as old as car traffic itself, had been dealt with in public debates primarily as a problem of young, male drivers. Now, there was an increasing ethnicization of a phenomenon which before had been discussed chiefly as a generation- and gender-specific topic. This was due to the numerous reports in which Amirs, Ahmeds, and Igors from the Kosovo, from Serbia-Montenegro and Macedonia played the main role. Belonging to an ethnicity became the essential pattern of interpretation and the omnipresent frame of orientation within the debate on this everyday issue. ${ }^{20}$ Such processes of ethnicization are social systems of organization which help to create demarcations between actors and groups on the basis of self-ascribed and other-ascribed identities and images. In this manner, cultural differences are socially organized and these constructed differences model the perception of members as well as of non-members of ethnic groups. By means of pictures and texts, social conflicts were stylized as undeniable "facts" of ethnic characteristics. Whether the "facts" were true or not becomes trivial, what is important is solely whether the stories are believed to be true.

By mixing the debate on speed maniacs and that on the naturalization bills, it was possible to depict people of Southeast European origin as deficient regarding their contribution to society and as representing a hazard for Switzerland. By way of exclusion and closing off, the "spatial construct

19 | Foucault 1979.

20 | Garhammer 2003, p. 179-201; Bukow 1996, p. 6-7.

Bereitgestellt von | Universitaetsbibliothek Basel 
of Switzerland" and the "Swiss national mentality" was reproduced, and the so called "Balkans region" and the people from there were presented as a spatial, political, social and cultural counter-image. The reasons for this must be seen in the 1990 s and in the resurrection of the negative image of this region, which was in particular communicated by the mass media. The violent struggles in Southeast Europe established and reinforced the stubbornly maintained collective external perception of the "Balkans" as Europe's "problematic region"- the "Balkans region" as a spatial counterimage to Western and Central Europe, so to speak the "Balkans region" as a kind of "anti-Europe".

\section{Concluding Remarks}

Images play an important role in this discursive construction of stereotyped ideas. In the context of the media debate, authors, those depicted as well as recipients mutually refer to visually set symbols and the images connected to imagination. It is only the power of the discourse, and here above all of the visual discourse, which creates that what it names. In this sense, the creation of stereotypes must be considered a performative actas does Judith Butler-which through constant repetition and presentation creates ever more manifestations of the stereotype. ${ }^{21}$

Thus, the debate on the "speed maniacs from the Balkans"-and here I will conclude my remarks-is an example of how certain social or ethnic groups are turned into a topic, above all a visual topic, because in a given political situation they are considered a current issue. As regards depiction and perception, they experience particular reserve or attention by the receiving society-and often both at the same time. The discourse, in particular the visual discourse, has the power to depict them as normal or different, as integratable or unintegratable, to construct them as an ethnicity and pass judgment on them with the aid of cultural or even biological arguments and thus to create the basis for the way in which they are dealt with.

This means that the discursive communication of certain "images of people", for example the type of the "speed maniacs from the Balkans", has not only consequences at the abstract-cultural level but also explicit effects on the everyday and practical living environment of individual groups. The media debate on speed maniacs, for example, resulted in various Swiss insurance companies deciding to demand an insurance premium which was up to thirty per cent higher for new customers of Southeast European origin. Some insurance companies even refused to accept such new customers at all. Whether the political vote on the "naturalization bills" would have had a different result, is a matter of speculation. However, it is an example of how by means of media images and

21 | Butler 2001, p. 35-36. 
texts strategies of belonging and closing-off are made to work. This debate was used to create a confrontation between an imagined "we-group" and some constructed "others". The others in this case were the "speed maniacs from the Balkans". Young men from Southeast Europe who through other media debates on unemployment, crime and macho behaviour had already been and still are, deeply rooted in the perception of many recipients as a "problematic collective".

\section{LIST OF FiguRES}

Figure 1: Photo report: Ruedi Leuthold. 2004. "Wir Verfluchten.“ Das Tagesanzeiger-Magazin 39: p. 22-33.

Figure 2: Photo report: Daniel Jaggi and Yvonne Kummer. 2004. "Der gefährlichste Raser der Schweiz.” SonntagsBlick 38: p. 2-3.

\section{BiBLIOGRAPHY}

Argast, Regula. 2007. Staatsbürgerschaft und Nation. Ausschliessung und Integration in der Schweiz 1848-1933. Göttingen: Vandenhoeck \& Ruprecht.

Bischoff, Christine. 2006. "Die Raser vom Balkan - Bemerkungen zur Inszenierung eines Medienspektakels.” Kuckuck. Notizen zur Alltagskultur 21: p. 10-15.

Bude, Heinz. 2004. "Das Phänomen der Exklusion. Der Widerstreit zwischen gesellschaftlicher Erfahrung und soziologischer Rekonstruktion." Mittelweg 36 4: p. 3-15.

Bukow, Wolf-Dietrich. 1996. Feindbild Minderheit. Zur Funktion von Ethnisierung. Opladen: Leske and Budrich.

Butler, Judith. 2001. Körper von Gewicht: die diskursiven Grenzen des Geschlechts. Frankfurt/M.: Suhrkamp.

Elias, Norbert/Scotson, John. L. 1993. Etablierte und Aussenseiter. Frankfurt/M.: Suhrkamp.

Foucault, Michel. 1979. Überwachen und Strafen. Frankfurt/M.: Suhrkamp.

Garhammer, Manfred. 2003. "Der Fall Ahmet und die Ethnisierung von Jugendgewalt.” In Die Ethnisierung von Alltagskonflikten, ed. Axel Groenemeyer and Jürgen Mansel, p. 179-201. Opladen: Leske and Budrich.

Hall, Stuart. 2004. “Das Spektakel des 'Anderen'.” In: Ideologie, Idenität, Repräsentation. Ausgewählte Schriften 4, ed. Stuart Hall, p. 108-166. Hamburg: Argument Verlag.

Hohmeier, Jürgen. 1975. "Stigmatisierung als sozialer Definitionsprozess.” In Stigmatisierung: Zur Produktion gesellschaftlicher Randgruppen, Band 1, ed. Manfred Brusten and Jürgen Hohmeier, p. 5-24. Neuwied: Luchterhand. 
Kämpf, Philipp. 2008. Die Jugo-Schweiz: Klischees, Provokationen, Visionen. Zürich: Rüegger.

Leuthold, Ruedi. 2004. "Wir Verfluchten.” Das Tagesanzeiger-Magazin 39: p. 22-33.

Osten, Marion von. 2005. "Die Fahrbahn ist ein graues Band. Überlegungen zu einigen privaten Fotos mit Automobilen." 31 - Das Magazin des Instituts für Theorie der Gestaltung und Kunst, Zürich 6/7: p. 25-33.

Sachs, Wolfgang. 1990. Die Liebe zum Automobil. Ein Rückblick in die Geschichte unserer Wünsche. Reinbek bei Hamburg: Rowohlt.

Schär, Markus. 2004. "Kosovo-Albaner: Gebremster Wille zur Anpassung.” Die Weltwoche 40: p. 12. 